\title{
暖地におけるイネ科青㺫飼料の合理的な利用法に関する研究
}

\section{XII. トウモロコシ，スーダンダラス，ソルゴーおよびテオシントの飼料価值}

\author{
丹比 邦保・小山 一夫
}

(爱媛大学農学部)

(1967.2. 20 受付)

臬作のイネ科青刈飼料の播種期および生育ステージ別 の飼料価値に関する研究では, 鉿木ら 2,31 のトウモロコ シとソルゴーの報告がある。すなわち，前者で注生育時 期による飼料価值の 変化が 播種期により著しく異なる

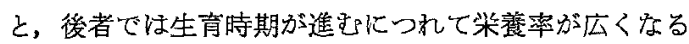
とそれぞれ述べられている。

暖地では,トウモロコシは雄穂抽出期前から乳熟初期, スーダングラスとソルゴーは出穂期がら乳熟期前, テオ シントは 1 番草を 8 月の盛夏期, 2 番草 10 月の出穗 期にそれぞれ青刈利用している。

本報では，これらの青刈期間中の飼料価值を比较検討 するために消化試験安行なつたので，その概要を報告す る.
なお，実施場所は本学農学部付属農場で，実施期間柱 1964 年 3 月から 11 月をでと 1965 年 4 月から 11 月 までとの間である。

\section{材料および方法}

供試材料は 1964 年 3 月， 4 月， 6 月， 7 月和よび 8 月に播種したトウモロコシ (長交 161 号)，1964 年 4 月 に播種したスーダングラス (在来種)，1965 年 4 月と 5 月とに播種したンルゴーー・イブリッド)および 1965 年 5 月に播種したテオシントである.

これら偂前述の青刚給与の刚取法に準じ，それでれの 刈取期間家原則として 25〜35 日としたが，それらの区 分は第 1 表の通りである.なお，各作物ごとの刚取時期

第 1 表 消化試験 の供試材料

\begin{tabular}{|c|c|c|c|c|c|c|}
\hline 作 物 名 & 播 種 期 & 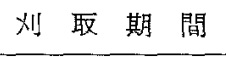 & 生 & 育 日 & 数 & 生育不 $\bar{\tau}-シ ゙$ \\
\hline トウモロコシ & $\begin{array}{c}64.3 .31 \\
4.28 \\
6.11 \\
7.12 \\
8.6\end{array}$ & $\begin{array}{l}6.18 \sim 7.3 \\
6.29 \sim 7.29 \\
7.21 \sim 8.25 \\
8.26 \sim 9.24 \\
9.25 \sim 10.29\end{array}$ & $\begin{array}{l}79 \\
63 \\
41 \\
46 \\
51\end{array}$ & $\begin{array}{l}\text { 日 } \sim 95 \\
\prime \prime \sim 93 \\
\prime \prime \sim 76 \\
\prime \prime \sim 74 \\
\prime \prime \sim 85\end{array}$ & $\begin{array}{l}\text { 日 } \\
11 \\
11 \\
11 \\
\prime \prime\end{array}$ & 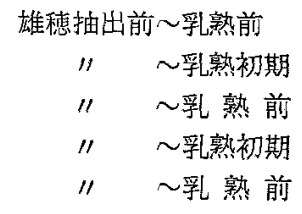 \\
\hline スーダングラス & '64. 4.14 & $\begin{array}{l}6.17 \sim 7.17 \\
8.3 \sim 9.11^{*} \\
9.26 \sim 10.9^{* *}\end{array}$ & $\begin{array}{l}65 \\
48 \\
55\end{array}$ & $\begin{array}{l}\prime \prime \sim 95 \\
\prime \prime \sim 57 \\
\prime \prime \sim 29\end{array}$ & $\begin{array}{l}\prime \prime \\
\prime \prime \\
\prime \prime\end{array}$ & $\begin{array}{c}\text { 出穂 前 乳熟 前 } \\
\text { " } \sim " \prime \prime \\
\text { 開 花 揃 }\end{array}$ \\
\hline \multirow{2}{*}{ ソ ル $\exists$ - } & 65.4 .14 & $\begin{array}{l}6.17 \sim 7.17 \\
8.3 \sim 9.1^{*} \\
9.25 \sim 10.16^{* *}\end{array}$ & $\begin{array}{l}65 \\
48 \\
54 \\
\end{array}$ & $\begin{array}{l}11 \sim 95 \\
11 \sim 57 \\
11 \sim 36\end{array}$ & $\begin{array}{l}\prime \prime \\
\prime \prime \\
\prime \prime\end{array}$ & 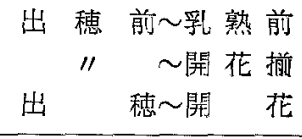 \\
\hline & '65.5.13 & $\begin{array}{l}7.24 \sim 8.23 \\
9.5 \sim 10.5^{*}\end{array}$ & $\begin{array}{l}73 \\
48 \\
\end{array}$ & $\begin{array}{l}\prime \prime \sim 103 \\
" \sim 44\end{array}$ & "l & 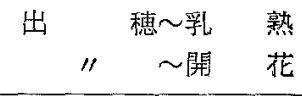 \\
\hline \multirow{2}{*}{ テオシント } & '65.5.13 & $\begin{array}{c}8.16 \sim 9.15 \\
10.15 \sim 10.29 *\end{array}$ & $\begin{array}{l}96 \\
61\end{array}$ & $\begin{array}{l}\| \sim 126 \\
\| \sim 45\end{array}$ & $\begin{array}{l}\prime \prime \\
\prime \prime\end{array}$ & 出穂前～出穂 揃 \\
\hline & $' 65.5 .27$ & $\begin{array}{c}8.18 \sim 9.17 \\
10.15 \sim 10.29 *\end{array}$ & $\begin{array}{l}84 \\
59\end{array}$ & $\begin{array}{l}\| \sim 114 \\
\| \sim 43\end{array}$ & $\begin{array}{l}\prime \prime \\
\prime \prime\end{array}$ & 出穗出 出穗揃 \\
\hline
\end{tabular}

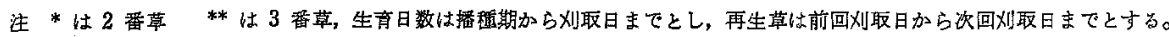


丹比・小山

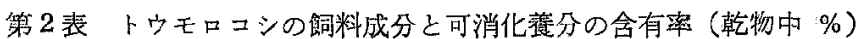

\begin{tabular}{|c|c|c|c|c|c|c|c|c|c|}
\hline 区 分 & No. & 播種期 & 有 機 物 & 粗蛋白䓄 & 粗脂肪 & 可溶無壆素物 & 粗 繊 維 & 粗欧分 & TDN \\
\hline \multirow{5}{*}{ 成 分 } & 1 & 3. 31 & 94.5 & 10.0 & 1.1 & 52.0 & 31.4 & 5.5 & \\
\hline & 2 & 4.28 & 94.2 & 9.9 & 2.3 & 50.6 & 31.4 & 5.8 & \\
\hline & 3 & 6.11 & 94.3 & 9.3 & 1.4 & 47.2 & 36.4 & 5.7 & \\
\hline & 4 & 7. 12 & 93.5 & 10.8 & 2.2 & 45.4 & 35.1 & 6.5 & \\
\hline & 5 & 8.6 & 95.3 & 10.7 & 1.2 & 49.7 & 33.7 & 4.7 & \\
\hline 平 均 & & & 94.4 & 10.1 & 1.6 & 49.3 & 33.6 & 5.6 & \\
\hline \multirow{5}{*}{$\begin{array}{l}\text { 可消化 } \\
\text { 養 分 }\end{array}$} & 1 & 3.31 & $57.4(61)$ & $6.1(61)$ & $0.6(55)$ & $33.2(64)$ & $17.5(56)$ & & 58.2 \\
\hline & 2 & 4.28 & $70.9(75)$ & $7.6(77)$ & $1.5(65)$ & $39.0(77)$ & $22.8(73)$ & & 72.8 \\
\hline & 3 & 6.11 & $63.8(68)$ & $5.7(61)$ & $0.7(50)$ & $33.0(70)$ & $24.4(67)$ & & 64.7 \\
\hline & 4 & 7.12 & $67.3(72)$ & $6.5(60)$ & $1.4(64)$ & $32.7(72)$ & $26.7(76)$ & & 69.1 \\
\hline & 5 & 8.6 & $65.9(69)$ & $5.9(55)$ & $0.6(50)$ & $36.8(74)$ & $22.6(67)$ & & 66.7 \\
\hline 平 均 & & & $65.1(69)$ & $6.4(63)$ & $1.0(57)$ & $34.9(71)$ & $22.8(68)$ & & 66.3 \\
\hline
\end{tabular}

の生育ステージはテオシント学除いてほぼ同一のステー ジにおいた。

試験材料は各供試作物において，一定間隔の各刈取日 ごとに乾草の等量ずつをとり，各刚取期間ごとに一括し て消化試験に供した。乾草の調政にあたつては，各刈取 日にカッターで 4〜 $7 \mathrm{~cm}$ に切断後, 天日で予乾し, 熱 風乾燥機 (1964 年は長府式, 1965 年は静岡式) で 40 $50^{\circ} \mathrm{C}, 6 \sim 8$ 時間乾澡して, 水分含量定 $20 \%$ とした.

供試動物はめて羊を使用し，1区 2 頭ずっとした。な 扮，消化試験は 1 期 12 日間とし，予㒂試験，本試験と も各 6 日とした。

蕒の調製にあたつては, 每日䔬の新鮮量を測定し，そ の $1 / 10$ ずつを分析用として $60 \sim 65^{\circ} \mathrm{C} て ゙$ 乾燥した. 試 験終了後試験期間中の霬を混合し，粉厒して分析にあて た.

供試材料㧠よび顀の分析は一般組成分析法1によつた。 なお，各成分および可消化羪分の含有率の比較は乾物 当りで行なつた.

結果

1. トウモロコシ

第 1 表に示すように 3 月 31 日，4月 28 日，6月 11 日，7月 12 日扎よ゙8月6日の各播種期のものについ て消化試験安行なつた。

各区の刚取間隔は刈取開始日から5 日目ごととし，刈 取時期はいずれも雄穂抽出期前加ら乳熟初期までの間 で，飼料成分および可消化養分の含有率は第 2 表の通り である・

i）飼料成分：5播種期に和ける各帅取時期の生育ス
テージはほほ同様であるが, 各成分の構成は可溶無窒素 物含量が 45.4〜52.0\% でもつとも多く，粗脂肪含量が 1. 1 2. $3 \%$ でもつとも少ない.この間, 粗蛋白質含量 で注播種期の遅いNo. 4-No. 5 が多く, 可溶無空素物 含量では播種期の早いNo. 1・No. 2 が多く, 粗瀻維含 量では生育期間の短い No. 3 - No. 4 が多く, 粗脂肪含 量では一定の傾向がみられなかつた。

ii）可消化養分：各播種期における可消化養分の含 有率恃可溶無咥䒺物, 粗瀻維, 粗蛋白質, 粗脂肪の順に 减少した。なお，有機物および各成分の消化率る2ると， 有機物は 61〜 75\%，粗蛋白質は 55〜77\%，粗脂肪始 50〜

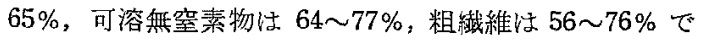
あつた.このうち消化率の高いのがNo. 2, 低いのが No. 1 であつた。

DCP 含量は No. 2 が $7.6 \%$ でもつをも多く, No. 3 が $5.7 \%$ でもつとす少なく, TDN 含量は No. 2 が $72.8 \%$ でつとも多く， No. 1 万ั $58.2 \%$ でもつとる 少なからた。

2. スーダンダラス

第1表に示すように4月 14 日播種の $1 \sim 3$ 番草につ いて消化試䮖定行なつた。

各区の刈取間隔は，刚取開始日から 1 番草が 10 日目 ごと，2番草が 13 日目ごと，3番草が 7 日目ごとであ り，㺫取時期は 1，2 番草汃出襢期汃ら乳熟期の間， 3 番草が開花撤期で，これらの成分および可消化養分の含 有率は第3表の通りである。

i）飼料成分：1〜3 番草まで生育ステージはほ涪同 椂のものであるが，各成分の棈成は可溶無窒素物含量が 42. 4 46.1\% でもつとも多く，粗脂肪含量が $1.6 \sim$ 
主な夏作青灲作物の飼料価値

第 3 表 スーダンク゚ラスの飼料成分と可消化養分の含有率（乾物中 \%)

\begin{tabular}{|c|c|c|c|c|c|c|c|c|c|}
\hline 区 分 & No. & 刚取回数 & 有 機 物 & 粗蛋白質 & 粗脂肪 & 可溶無窒菜物 & 粗 繊 維 & 粗灰分 & TDN \\
\hline \multirow{3}{*}{ 成 分 } & 1 & 1 & 93.6 & 10.7 & 1.6 & 46.1 & 35.2 & 6.4 & \\
\hline & 2 & 2 & 95.2 & 10.8 & 1.8 & 45.9 & 36.7 & 4.8 & \\
\hline & 3 & 3 & 94.1 & 10.4 & 2.7 & 42.4 & 38.6 & 5.9 & \\
\hline 平 均 & & & 94.3 & 10.6 & 2.0 & 44.8 & 36.8 & 5.7 & \\
\hline \multirow{3}{*}{$\begin{array}{l}\text { 可消华 } \\
\text { 卦 分 }\end{array}$} & 1 & 1 & $52.5(56)$ & $5.3(50)$ & 0.5 (31) & $27.3(59)$ & $19.4(55)$ & & 53.1 \\
\hline & 2 & 2 & $49.4(52)$ & $6.6(61)$ & $0.6(33)$ & $24.2(53)$ & $18.0(49)$ & & 50.2 \\
\hline & 3 & 3 & $54.6(58)$ & $5.0(48)$ & 0.9 (33) & $25.3(62)$ & $22.4(58)$ & & 55.7 \\
\hline 平均 & & & $52.2(55)$ & $5.6(53)$ & $0.7(32)$ & $25.9(58)$ & $19.9(54)$ & & 53.0 \\
\hline
\end{tabular}

注 ( ) 内经消化率

第4表 ソルゴーの飼料成分と可消化養分の含有率（乾物中. \%)

\begin{tabular}{|c|c|c|c|c|c|c|c|c|c|}
\hline 区 分 & No. & 则取回数 & 有機 物 & 粗蛋白質 & 粗 脂 肪 & 可溶無空素物 & 粗 織 維 & 粗灰分 & TDN \\
\hline \multirow{5}{*}{ 成 分 } & 1 & 1 & 95.0 & 8.0 & 1.5 & 50.8 & 34.7 & 5.0 & \\
\hline & 2 & 2 & 94.2 & 11.1 & 1.6 & 45.3 & 36.2 & 5.8 & \\
\hline & 3 & 3 & 93.8 & 10.0 & 1.7 & 44.8 & 37.3 & 6.2 & \\
\hline & 4 & 1 & 94.6 & 7.9 & 1.4 & 48.2 & 37.1 & 5.4 & \\
\hline & 5 & 2 & 93.2 & 10.2 & 1.7 & 44.0 & 37.3 & 6.8 & \\
\hline 平 均 & & & 94.2 & 9.4 & 1.6 & 46.9 & 36.3 & 5.8 & \\
\hline \multirow{5}{*}{$\begin{array}{l}\text { 可消化 } \\
\text { 養 分 }\end{array}$} & 1 & 1 & $58.4(62)$ & $3.8(48)$ & $0.8(53)$ & $32.9(65)$ & $20.9(60)$ & & 59.4 \\
\hline & 2 & 2 & $64.8(69)$ & $7.5(68)$ & $0.5(31)$ & $30.3(67)$ & $26.5(73)$ & & 65.4 \\
\hline & 3 & 3 & $55.5(59)$ & $5.6(56)$ & $0.6(35)$ & $26.9(60)$ & $22.4(60)$ & & 56.2 \\
\hline & 4 & 1 & $60.0(63)$ & 4.3 (55) & $0.7(50)$ & $30.8(64)$ & $24.2(65)$ & & 60.9 \\
\hline & 5 & 2 & $53.6(58)$ & $5.7(56)$ & $0.6(35)$ & $24.2(55)$ & 23.1 (62) & & 54.4 \\
\hline 平 均 & & & $58.5(62)$ & $5.4(57)$ & $0.6(41)$ & $29.0(62)$ & $23.4(64)$ & & 59.3 \\
\hline
\end{tabular}

注（）内消化率, No. 1 No. 3 は 4 月 14 日播程，他は 5 月 13 日播棰でる。

2.7\% でもつとも少ない.なお， No. 3 は No. 1・No. 2 と比べて粗蛋白質と可溶铔窒素物の会量が少なく，粗 脂咗と粗瀻維の含量が多いのが目立つ.

ii) 可消化養分：各刘取回数別における可消化養分 の含有率怯可溶無窒素物が 24.2 27.2\%でもつとも多 く，粗脂肪が $0.5 \sim 0.9 \%$ でもつとも少ない.な祘，有 機物なる゙各成分の消化率をみると,有機物は 52 2 58\%， 粗蛋白質到 $48 \sim 61 \%$ ，粗脂肪は 31 33\%，可溶無空素 物は 53 62\%，粗織維は 49〜58\% であつた。

DCP 含量任 $5.0 \sim 6.6 \%$, TDN 含量注 $50.2 \sim 55.7 \%$ であり, 各区間の DCP 含量, TDN 含量に大きな差異 加ない。

\section{3. ソルゴー}

第 1 表に示すように 4 月 14 日と 5 月 13 日の 2 播種 期の1〜3 番草について消化試験行なつた。
各区の刚取間隔は 4 月播種のものはスーダングラスと 同様であり， 5 月播種のるのは刚取開始日から 10 日目 ごとであつた。な拉，4 月播種の 3 番草と 5 月播種の 2 番草とは生育ステージが開花期であつた。こ扎らの成分 执よび可消化養分の含有率法第 4 表の通りである。

i）飼料成分：No. $3 \cdot$ No. 5 の生有ステージは他の そのに比べてやや若いステージであるが，各成分の構成 は可溶無窒素物含量㣻 $44.0 \sim 50.8 \%$ でつとも多く， 粗脂肪含量が $1.4 \sim 1.7 \%$ であつと少ない，なお， 9 月から 10 月までの刈取りである No. 3 と No. 5 とは 他の刈取期のるのに比べて粗脂脏子粗瀻維の含量が多 く，可溶無窒素物合量の少ないのが目立つ.

ii）可消化養分：各刈取時期別の可消化養分の含有 率致いずれる可溶無室菜物がもつとも多く，粗脂肪がも つとも少ない。なお，有機物および各成分の消化率をみ 
丹比・小山

第 5 表 テオシントの飼料成分と可消化䠽分の含有率（乾物中％）

5 月 13 日播種

\begin{tabular}{|c|c|c|c|c|c|c|c|c|c|}
\hline 区 分 & No. & 则取回数 & 有 機 物 & 粗蛋白質 & 粗 脂肪 & 可溶無案素物 & 組 緎 維 & 粗质分 & TDN \\
\hline \multirow{2}{*}{ 成 分 } & 1 & 1 & 93.4 & 9.6 & 2.4 & 43.6 & 37.8 & 6.6 & \\
\hline & 2 & 2 & 94.9 & 13.5 & 1.9 & 47.4 & 32.1 & 5.1 & \\
\hline \multirow{2}{*}{$\begin{array}{l}\text { 可消化 } \\
\text { 養 分 }\end{array}$} & 1 & 1 & $66.6(71)$ & $7.2(75)$ & $1.8(75)$ & 28.1 (65) & $29.5(78)$ & & 68.9 \\
\hline & 2 & 2 & $60.5(64)$ & $8.3(62)$ & $1.3(68)$ & $30.4(64)$ & $20.5(64)$ & & 62.1 \\
\hline
\end{tabular}

5 月 27 日播偅

\begin{tabular}{|c|c|c|c|c|c|c|c|c|c|}
\hline 区 分 & No. & |邚取回数 & 有 機物 & 粗蛋白質 & 粗 脂肪 & 可溶無案素物 & 粗 緎 維 & 粗质分 & TDN \\
\hline \multirow{2}{*}{ 成 分 } & 3 & 1 & 93.8 & 12.2 & 2.1 & 43.4 & 36.1 & 6.2 & \\
\hline & 4 & 2 & 93.9 & 12.2 & 1.4 & 49.8 & 30.5 & 6.1 & \\
\hline \multirow{2}{*}{$\begin{array}{l}\text { 可消化 } \\
\text { 養 分 }\end{array}$} & 3 & 1 & $63.9(68)$ & $6.8(56)$ & $1.4(67)$ & $28.6(66)$ & $27.1(75)$ & & 65.7 \\
\hline & 4 & 2 & $54.8(58)$ & $6.1(50)$ & $0.7(50)$ & $32.4(65)$ & $15.6(51)$ & & 55.7 \\
\hline
\end{tabular}

伡 ( ) 内は消化渗

\begin{tabular}{l|l|l|l|l|l|l|l}
\hline \hline & 有 機 物 & 粗蛋白質 & 粗 脂 肪 & 可溶無窒素物 & 粗 緎 維 & 粗灰分 & TDN \\
\hline 1 番 草 成 分の平均 & 93.6 & 10.9 & 2.3 & 43.5 & 37.0 & 6.4 & \\
1 番草可消化養分の平均 & $65.3(70)$ & $7.0(64)$ & $1.6(70)$ & $28.4(65)$ & $28.3(77)$ & & 67.3 \\
2 番 草 成 分の 平 均 & 94.4 & 12.9 & 1.7 & 48.6 & 31.3 & 5.6 & \\
2 番草可消化養分の平均 & $57.7(61)$ & $7.2(56)$ & $1.0(59)$ & $31.4(65)$ & $18.1(58)$ & & 59.0 \\
\hline
\end{tabular}

ると, 有機物は 58〜69\%, 粗蛋白質忹 $48 \sim 68 \%$, 粗脂 肪は 31 53\%, 可溶無窒素物は 55 67\%, 粗䋐維は 60 $73 \%$ であつた。

DCP 含量は $3.8 \sim 7.5 \%$ で 1 番草の No. 1, No. 4 の少ないのが目立ち，TDN 含量は $54.3 〜 65.4 \%$ であ つた.

4. テオシント

第1表に示すように5月 13 日と 5 月 27 日の 2 播種 期の 1〜2 番草について消化試験を行なつた.

1 番草法いずれる生育途上のものであつて刈取間隔は 刈取開始日和ら 10 日目ごと，2 番草峙出穂前から出穂 期までのもので刈取間隔は刈取開始日から7日目ごとで あつた．これらの成分㐨よび可消化養分の含有率柱第 5 表の通りである。

j) 飼料成分：若い刚取時期の No.1・No. 3 以粗脂 肪と粗織維の含量が多く, 出穂期の No. $2 \cdot$ No. 4 は可 溶無窒素物含量が多いが，これはンルゴーと同様であつ た.

ii）可消化養分：各刈取時期別の可消化養分の含有 滦はいずれも可溶姃窒素物が多く，粗脂肪が少ない：な 求，有機物と各成分の消化率をみると，有機物は 58
$71 \%$ ，粗蛋白質忹 $50 \sim 75 \%$ ，粗脂肪注 $50 \sim 75 \%$, 可溶 無窒素物は 64〜66\%，組繊維は 51〜78\% であつた。

DCP 含量注 $6.1 \sim 8.3 \%$, TDN 含量恬 $55.7 \sim 68.9 \%$ であり，後者は 1 番草が 2 番草より多かつた.

考察

1. トウモャコシ

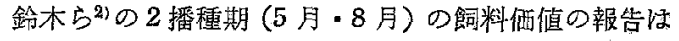
生草に郝ける開花始，絹糸抽出期および乳熟期の生育ス テージのもので，本報は乾草に打ける生育期間別のもの であり，その他汇気像あるいは土じょうの条件の相違が あるため簡単には比較できないが，生育日数の期間分ほ ぼ同じものについて DCP 含量と TDN 含量を比較する と次のようである。

鈴木らの 5 月播種の 3 刈取期のるのは開花始加ら順に DCP 含量以 $10.5 \%, 6.6 \%, 4.4 \%$, TDN 含量は $73.9 \%$, $69.8 \%, 57.3 \%$ であり,8 月播種のものはそれぞれ DCP 含量分 $11.3 \%, 10.4 \%, 8.1 \%$, TDN 含量怔 $69.6 \%$, $59.3 \%, 60.8 \%$ である.本報のものは 4 月播種の DCP 含量が $7.6 \%$, TDN 含量が $72.8 \%, 8$ 月播種の DCP 含量が $5.9 \%$, TDN 含量が 66. $7 \%$ である。:このため 
鈴木らの結果と同様化，本報でる早い播種期のものと遅 い播種期のものの間に飼料価值の差異のあること唯うか がえる.

5 播種期の消化率を比較すると，有機物では No. 2 ・ No. 4 が高く, No. 2 と No. 1 - No. 5 および No. 4 と No. 1 との間にそれぞれ 統計的有意差 $(\mathrm{P}<.001)$ が認 められ，粗蛋白質では No. 2 がもつとも高く，No. 2 と No. 1 - No. 3 - No. 4. No. 5 の間に統計的有意差 $(\mathrm{P}<$ .01) が認められ，粗脂肪では No. 2. No. 4 が高く, No. 2 - No. 4 と No. 1 - No. 3 - No. 5 の間飞統計的有 意差 $(\mathrm{P}<.001)$ が認められ，可溶無空素物では No. 2 ・ No. 5 が高く, No. $2 \cdot$ No. 5 と No. 1 の閻に統計的有 意差 $(\mathrm{P}<.001)$ が認められ，粗瀻維では No. 1 が著し く低く, No. 4 と No. $1 \cdot$ No. 3 およびNo. $2 \cdot$ No. 3 • No. 5 と No. 1 との間にそれぞれ統計的有意差 $(\mathrm{P}<$ .01) が認められる.

DCP 含量には統計的有意差は認められないが，TDN 舍量は No. 2 がもつとも多く, No. 1 のもつとも少な いのが目立ち, No. 2 と No. $1 \cdot$ No. $3 \cdot$ No. $4 \cdot$ No. 5 乱よびNo.3・ No. $4 \cdot$ No. 5 と No. 1 との間に乞れぞ れ統計的有意差 $(\mathrm{P}<.001)$ が認められる.

ての結果, 気温が上昇していない3月播種のものの饲 料価值が著しく劣り, 気温上昇期の 6 月播種のものは生 育ステージの展開はむつとる早いが飼料価值では 4 月播 種のむのより劣ることが認められる。このため，青刈法 で飼料価值を高めるには 4 月播種を中心とするのがよい と思わ机る。

2. スーダングラス

3刈取期の有機物之各成分の消化率, DCP 含量就よび TDN 含量の比較では，粗蛋白質の消化率にのみ No. 2 と No. $1 \cdot$ No. 3 の間纪統計的有意差 $(\mathrm{P}<.05)$ 隹認的 られる.このため, 同じ生育ステージのものでは刈取回 数により飼料価值に差巽は認められない。

3. ソルゴー

4 月播種の 3 刈期と 5 月播種の 2 刈取期のものの有機 物之各成分の消化率比較すると，有機物では No. 2 次 もつとも高く，No. 2 と No. $3 \cdot$ No. 5 の間に統計的有 意差 $(\mathrm{P}<.01)$ が認められ，粗蛋白質では No. 2 がす つとも高く, No. 2 と No. $1 \cdot$ No. $3 \cdot$ No. $4 \cdot$ No. 5 极 よび No. $3 \cdot$ No. 5 と No. 1 との間にそれぞれ䖻計的 有意差 $(\mathrm{P}<0.1)$ が認められ，粗脂肪では No. 1・No. 4 が高く, No. 1 - No. 4 と No. $2 \cdot$ No. $3 \cdot$ No. 5 の間 に統計的有意差 $(\mathrm{P}<.001)$ が認められ，可溶無登素物 では No. 5 がもつとも低く, No. $1 \cdot$ No. 2 と No. 5 の間に統計的有意差 $(\mathrm{P}<.01)$ が認められ，粗瀻維では
No. 2 驾つとも高く, No. 2 子 No. $1 \cdot$ No. $3 \cdot$ No. 4・No. 5 の間任統計的有意差 $(\mathrm{P}<.05)$ が認められる.

DCP 含量には統計的有意差洼認めら秃ないが，TDN 含量は No. $2 \cdot$ No. 4 が多く, No.2・No. 4 と No.3・ No. 5 の間汇統計的有意差 $(\mathrm{P}<.01)$ 加認められる.

このため，2 播種期己も 7 月下旬から 9 月上旬までの 刈取りのひのが TDN 合量がをさると推測される.

\section{4. テオシント}

5 月播種の 4 朾取期の有機物之各成分の消化率を比較 すると，有機物では No. 1 ・ No. 3 の若い刚取時期のも のがすぐれ，No. 1 と No.2・No.4 おちよ゙ No. $2 \cdot$ No.3 と No. 4 との間にとれぞれ統計的有意差 $(\mathrm{P}<.05)$ が 認められ，粗蛋白質では No. 1 がもつとも高く，No. 1 と No. 3・No. 4 の間に統計的有意差 $(\mathrm{P}<.01)$ が認め ら东, 粗脂肪で注 No.4 が著しく低く, No. $1 \cdot$ No 2 ・ No. 3 と No. 4 の間飞統計的有意差 $(\mathrm{P}<.01)$ が認め られ，可溶無空素物では統計的有意差は認められないが， 粗瀻維では No.1・No. 3 が高く, No. 1 - No. 3 乙 No. $2 \cdot$ No. 4 战よび No. 2 と No. 4 との間にそれぞれ統 計的有意誈 $(\mathrm{P}<.01)$ が認められる.

DCP 含量には統計的有意差は認められないが，TDN 含量は No. $1 \cdot$ No. 3 が多く, No. 1 と No. $2 \cdot$ No. 4 および No. 3 と No. 4 との間にそれぞれ統計的有意差 $(\mathrm{P}<.01)$ が認められる。

このため，2 播種期とも 1 番草の TDN 合量加 2 番草 のものより多いと思考される.なお，2 播種期問では青 刚用として 5 月 13 日播種が 5 月 27 日播種よりすぐれ ていると思われる。

$$
\text { 要 約 }
$$

代表的な夏作青刈作物の播種期と刈取回数別との飼料 価值を比輘するため，トウモロコシの 3 月から 8 月まで の 5 播種期, スーダングラスの 4 月播種, ソルゴーの 4 月, 5 月の 2 播種期およびテオシントの 5 月の 2 播種期 につマて消化試験学行なつた.

消化試験の材料法各刈取期間中（原則として 25 35日 間) の刘取日どとの乾草（水分含量 $20 \%$ ）の等量ずつを 採取して，これらを混合し，ぬん羊に給与した。

トゥモロコシの飼料価値は 3 月播種のるのがもつとも 劣り，4月播種のむのがるつともすぐれた：また，6月 播種のものは生育ステージの展開は早いが，3 月播種を 除く他の播種期のものより飼料価値が劣つた.

スーダングラスの飼料伍值は, 同じ生育ステージのも のであれば刈取回数による差異は認められなかつた。

ソルゴーの飼料価值は，同じ生育ステージでも 7 月下 
旬から9月上旬の刚取りのものがすぐれた。

テオシントの飼料価值は, 1 番草が 2 番草よりすぐれ， 播種期では早いものが遅いものよりすぐれた.

稿を終るにあたり，ご校圆とご指道をいただいた九州大学汇原鞂授、こ

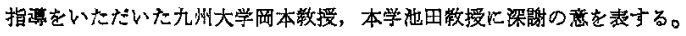

文献

1）京大農学部農芸化学教室編（1951）農芸化学実
験書, 中巻 2 版，503-512，産業図聙株式会社，東 京.

2）鈴木嘉兵衛・安藤交桜 ·阿部 林 (1963) 日畜 会屖，(34 別号) : 46 .

3）鈴木寋兵衛・安藤交桜・阿部 林・岡本道子(1964) 畜産の研究, 18: 1967-1968.

\title{
Résumé
}

\section{Studies on Reasonable Utilization of Soiling Forage Grasses in Warmer Districts of Japan}

XII. The Feeding Value of Corn, Sudangrass, Sorgo and Teosinte

\author{
Kuniyasu Tajı and Kazuo Koyama \\ (Faculty of Agriculture, Ehime University)
}

\begin{abstract}
In order to determine each feeding value of the different sowing time and that of the different cutting frequency of representative summer forage crops, the digestion trials of corn sown between March and August, sudangrass in April, sorgo in April and May and teosinte in May were conducted.

Materials for the digestion trials that were collected by the same quantity of hay (water content $20 \%$ ) on each cutting date in the cutting periods extended from 25 to 35 days in principle were mixed and fed for rams.
\end{abstract}

The results were as follows:

1. In the feeding value of corn, the minimal value was shown by the crop sown in March and the maximum value was shown by it sown in April. Now, the crop sown in June grew rapidly, but that feeding value was less than those of the crops sown in April, July and August.

2. The feeding value of sudangrass in the same stage of growth did not show significant difference, and so that had no relation with the cutting frequency.

3. In the feeding value of sorgo cut between the heading stage and the milk stage, that of the crop cut from late July to early September showed the best result.

4. In the feeding value of teosinte, that of the first cut (the vegitative stage) was richer than that of the second (the heading stage). In the crop sown in May, the feeding value of it by early sowing was richer than that by late sowing. 